de vouloir perpétuer les aspects caractéristiques de l'art nègre en liant la conception esthétique de ceux qui se sont détachés du passé traditionnel, à des formes, des couleurs, des motifs, des sons, des gestes, qui précisément sont, sur le terrain artistique, l'expression d'une mentalité désormais disparue.

Quant aux métiers indigènes proprement dits, on ne perdra de vue impunément que les nouvelles conditions de vie entraînent inévitablement la décadence du travail de l'osier, des fibres textiles, des peaux, de l'argile, du bois, de l'ivoire, du fer, du cuivre. En ces différents domaines, l'appauvrissement se poursuit fatalement chaque jour davantage. Aussi est-il de toute nécessité de conserver autant que possible tout ce que les arts et les métiers indigènes possèdent d'essentiellement vital pour l'avenir. Tel est le cas sans doute de la tradition décorative.

En attendant que la société indigène soit assez évoluée pour rénover ellemême son art, ce rôle de conservation, tout limité qu'il puisse paraître, nous semble fondamental. Il est en effet extrêmement délicat pour le colonisateur d'intervenir plus tôt d'une façon directe et active. La création d'ateliers spécialisés par exemple ne peut avoir qu'un succès fort douteux. A part le fait qu'ils ne se conçoivent guère qu'en vue de perfectionner les procédés coutumiers, il faut encore se demander si les perfectionnements dont ils sont susceptibles les mettront à même de concurrencer efficacement la superiorité de l'outillage et des productions européens. Dès lors, on aura non seulement rien changé aux données du problème, on aura encore couru le risque d'avoir amené des gens, qui nous avaient donné confiance, dans une situation sans issue. (Communication de $M$. le Professeur N. DE ClEENE.)

\title{
Vernacular Periodicals, No 18, Dikalo (Journal des Chrétiens de langue Douala. Edité par la Mission protestante française). Douala et Ndoungué, Caméroun.
}

La tribu des Douala n'est pas extrêmement nombreuse, mais pourtant sa langue est parlée. ou tout au moins comprise par la plupart des indigènes habitant la partie sud-ouest du Caméroun. C'est cette langue qu'emploie la Société des Missions évangéliques de Paris (Mission protestante française) dans quatre de ses six districts missionnaires de ce pays.

Depuis plusieurs années, cette Société publie en douala un petit journal qui s'appela Ngengeti (' l'Étoile') avant de devenir Dikalo ('Proclamation, message'). D'abord imprimé, ce bulletin ne fut ensuite que polycopié pendant un certain temps; enfin l'installation d'une petite imprimerie à la station de Ndoungué, vient de lui permettre de prendre un nouvel essor.

Cette publication est avant tout destinée aux catéchistes et moniteurs de la mission, mais elle est également envoyée à certains abonnés, dont le nombre augmente très sensiblement en ce moment. Le numéro de mai et juin 1934 a été expédié à 500 catéchistes ou autres employés de la mission et à plus de 700 
autres adresses. Voici le contenu de ce numéro: quelques explications et un plan de sermon pour le dimanche de Pentecôte, à l'intention des catéchistes; puis, des conseils et des règles à suivre pour les anciens d'église, une étude sur le mariage, les causes des divonces et le mal qui en découle; viennent ensuite des nouvelles du pays, une colonne réservée à la Société de tempérance ' $\mathrm{La}$ Croix bleue' et différents avis.

Les missionnaires et les pasteurs indigènes sont les principaux rédacteurs du Dikalo, mais beaucoup de lecteurs nous envoient aussi des articles. La question du mariage revient très souvent et l'auteur condamne toujours le système africain de mariage avec dot et l'oppose au mariage chrétien où l'élément essentiel est l'amour et la fidélité conjugale. D'autres articles étudient d'anciennes coutumes et là encore ceux qui les rédigent ont surtout pour but de dénoncer ce qui, à leur avis, entrave le développement moral et religieux de leur pays. (Communiqué par le missionaire M. С. B. Boury.)

\section{Tanganyika Notes and Records.}

We have much pleasure in directing the attention of our readers to this new Journal which is published half-yearly in Dar es Salaam. The annual subscription is ros. Among the subjects with which the Journal will deal are: flora and fauna, tribal traditions and history, customs and beliefs, boatbuilding and designs, types of native building, cultivation, irrigation and husbandry, the journeys of explorers, the history of such places as Kilwa, occurrences of stone implements, land tenure, secret societies, in short any subject relating to history, anthropology, and economic life. The more important articles appearing in the first number will be found mentioned in the Bibliography published in the July issue of Africa. Among these occurs the study by D. Thornton and N. V. Rounce, on 'Ukara Island and the Agricultural Practices of the Wakara'; it is an expert illustration of a case of intensive agriculture as practised by African natives.

\section{Ethnos.}

Ethnos is a new anthropological journal published by the Statens Etnografiska Museum, Stockholm, Sweden, and edited by G. Lindblom and S. Linné. It is international in scope, and the collaboration of foreign research students will be welcomed. The languages used will be English, French, and German. The first number, which comprises 16 pages, has articles in English only; none of them deals with an African subject. 